this is to ensure the rights of free access into the southern waters adjacent to the continental landmass. While this constitutes a leap over a major political hurdle and ensures a degree of order in the affairs of the continent, concomitantly it means looser control.

But the way has been opened for widening the international acceptance of the Treaty. The powers are considering inviting countries like West Germany to take part in the drawing up of a conservation regime, and international organisations like FAO could send observers.

In general the Treaty powers are anxious that any nation which is active in the area should accede, so that practical answers may be provided to practical questions. The Treaty is not closed, but the powers remain concerned about the possibilities of hegemony by an international organisa. tion which might diffuse authority still further and act not as a spur to action but as a block.

\section{Interim guidelines}

In the meantime, pending a definitive conservation regime for marine living resources, interim guidelines have been established. But they do not go beyond commitments to cooperate in research, coordinate shipping programmes and the exchange of catch statistics. The guidelines are accompanied by an acceptance of the need not to harvest the resources to the extent that there will be depletion.

In common with the principle adopted for marine living resources, control of the continent's mineral resources will not affect the position on territorial claims. But the Treaty powers have made their strongest commitment so far not to engage in mineral resource exploration until a regime of control has been established. This they intend to work towards. That said, however, there is no theoretical reason why a company should not start drilling in the area.

But this is not likely. Mining companies have already pointed to the distance of Antarctica from the world markets, the easier access available to resources in more hospitable climates and the expense of coming to terms with land covered by an ice sheet. The reservations of the companies are aiso held by experts from the Treaty powers. Their discussions and conclusions have taken a good deal of the pressure away from the need to reach quick solutions on control.

It is thought that it will take at least five years to amass the scientific and technical data necessary to provide a foundation for exploration and subsequent exploitation if conditions are to be found which safeguard the continental environment. Exploratory drilling itself might take ten years. In short the possibility of exploiting mineral resources is at least 15 years away, and probably more like 25 .

This assumes that the continent has hydrocarbon and other mineral resources economically worth exploiting. This is not proven. Geological history indicates the possibility, but so far only traces of mineralisation have been found on land, although unmetamorphosed tertiary sediments, of ten associated with oil and gas, have been discovered in areas offshore.

There is no technology available for oil production all the year round in Antarctica. The concepts for self-contained installations on the seabed exist but that is all. On land there is no technology available for drilling through the ice shelf.

Meanwhile the Treaty powers have the immediate problem of ensuring that the information they collect is made available to all who need it. The continent is vital within the international meteorological system, but the powers have discovered that only $25 \%$ of their observations ever reach the world system. Somewhere between the Antarctic research stations, the global telecommunications system and the world weather watch, the rest evaporates. $\square$

\title{
Ninety days and more
}

\section{As the Windscale inquiry draws to an end, Eben Wilson sums up progress}

\section{$\mathrm{T}^{\mathrm{H}}$} E Windscale inquiry has become an institution-the British democratic tradition gone wild in the interest of a public debate about nuclear power. In its ninety days, independent and government scientists from throughout Britain and abroad have for the first time been disagreeing and airing their uncertainties in public, while wrestling with the thorny problem of the close links between nuclear power development as an energy option and its social and political consequences for the future.

The inquiry has taken over a civic hall of 1960s' architectural utility in Whitehaven, a smail town perched almost inaccessibly on the Irish Sea coast to the West of England's Lake District, eleven miles from Windscale. Inside one large room, the inquiry inspector, $\mathrm{Mr}$ Justice Parker, a high court judge, and his two assessors, Sir Frank Warner and Sir Edward Pochin, sit trapped at a green baize table among a pile of papers. They look out on five rows of lawyers, scientists and environmentalists who hide behind their green baize tables loaded with documents, articles and studies on nuclear power.

Out of that sea of paper a pile of daily transcripts now four feet high has appeared. Many say these will become an historic document, the quintessential reference work for the international nuclear debate.

Although the inquiry is specifically trying to decide on a planning application to build an oxide fuel reprocessing plant (THORP) alongside Britain's present Magnox reprocessing facilities at Windscale, it has become the platform for discussions on Britain's future energy options. Ranged against British Nuclear Fuels (BNFL), who own the present plant, is an array of pressure groups and individuals, from the established Friends of the Earth (FOE) to local housewives worried about their children.

The Friends of the Earth have waged war on the economic case for reprocessing and have convinced the inquiry that the British taxpayer will have to pay somewhere between $£ 300$ million

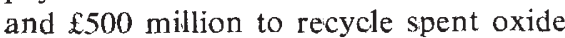
fuel from Britain's advanced gas cooled reactors (AGR). The exact figure depends on where the price of uranium lies between $\$ 30$ per pound and $\$ 100$ per pound, and a notional price for plutonium above $£ 90,000$ per tonne. BNFL estimate an ex-works price for recycled fuel of $£ 260,000$ per tonne or above depending on whether permission is given for a 1,200 tonne per year plant with capacity for foreign reprocessing contracts, or a 600 tonne a year plant only for British fuel.

The FOE alternative consists of importing uranium for fuel, storing fuel elements on a long term basis and abandoning reprocessing. They have asked for a ten-year delay to THORP while long term storage is researched. If this fails, they say, the delay would at least give time to try to evolve safeguards against plutonium proliferation.

British Nuclear Fuels have an unhappy history of Magnox fuel elements deteriorating in their cooling ponds at Windscale and have revealed that AGR fuel, still less than ten years old, is already showing signs of corrosion. 
They view reprocessing as good waste management and point out that against the cost of reprocessing has to be put the cost of fuel storage, which nobody knows, and that storage itself does not guarantee that fuel elements will not eventually have to be dealt with either by glassification (at $£ 450,000$ per tonne), or even reprocessing to prepare fuel for glassification.

\section{Scientific struggles}

The real scientific struggle has been over the level of discharges from Windscale into the Irish Sea. These contain $Z_{\text {}}$ long-lived $\alpha$-emitters, ${ }^{239} \mathrm{Pu}$ and ${ }^{241} \mathrm{Am}$ and shorter lived isotopes of ${ }^{137} \mathrm{Cs}$.

Hours of evidence and reams of paper have shown disturbing inadequacies in the research done by the Ministry of Agriculture, Fisheries and Food (MAFF) and the Fisheries Radiological Laboratory (FRL) into transuranic marine pathways back to man's environment. The Isle of Man government produced Dr Vaughan Bowen, an expert in marine pollution from America, who castigated the FRL for its methods of measuring silt movements and biological pathways. Dr Brian Wyne for the Network for Nuclear Concern and a research lecturer at Lancaster University, cross-examined both MAFF and FRL at length on the critical group method $\partial$ of evaluating derived working limits for the consumption of contaminated organisms. Cod, muscles, porphyra (an edible seaweed), silt and more have been metaphorically and literally dissected to examine possible synergistic effects of low level contamination or the possibility of biological systems concentrating transuranics.

The result of the public analysis has been a mixture of scientific humility and confusion, and human arrogance and anger, each coming from both objectors and government scientists. Researchers using the transcripts after the inquiry will find long lists of documents showing the present confusion over the effects of low level radiation and the concept of a threshold for radiation below which humans are not affected.

Much evidence has been presented attacking the present International Commission on Radiological Protection (ICRP) limits. Dr Sadao Ichikawa from the Laboratory of Genetics at Kyoto University, Japan, in particular, presented disturbing evidence on the long term genetic effects of low level radiation.

The weight of all the technical evidence threatened to swamp the inquiry in its sixteenth week in a shower of facts when Justice Parker admitted that he and his assessors were falling behind under a deluge of documents.

\section{Making assessment: Warner, Pochin, Parker}

Equally, however, it has given the inquiry a certain authority, so that when Thomas B. Stoel from the National Resources Defense Council (NRDC) in Washington, DC, came to suggest that a full environmental impact study should be done for Windscale, Justice Parker was able to wonder aloud and a little wearily what he had been doing for the past 74 days.

The overall impression of the discharge arguments has not been that BNFL are pumping death every day into the sea, but rather that nobody yet really knows what happens to the radiopathogens once they get into the silt and marine food chains. Both $\mathrm{Dr}$ Wynne and Dr Bowen have pleaded that independent bodies be funded to allow a plurality of research into radiation hazards.

Justice Parker could be fongiven for sighing and wondering what all this has to do with building a reprocessing plant now. He is known to favour risk comparisons with other industries and a practical approach to hazards. $\mathrm{He}$ has acted swiftly on the more alarmist claims made at the inquiry. The Lake District's water has been tested for tritium, air sampling is being done at Ravenglass a few miles from Windscale, and twenty local volunteers are undergoing whole-body monitoring tesits at the plant. The scientific groups on both sides of this application have agreed that the tests will prove nothing -an ironic consensus, as witnesses have usually retreated behind the armour plating of "not enough information" when under pressure.

The Oxford Political Ecology Research Group (PERG) faced the problem of getting enough information when they attempted to calculate the consequences of an accident at Windscale. A computer programme was provided by the Safety and Reliability Directorate, but agreement could not be reached on a possible mechanism for an accident that would provide the inputs to the programme.

\section{Stunning realism}

Justice Parker has gained a reputation for realism. He stunned the objecting groups at the beginning of July by declaring that alternative energy strategies in place of nuclear power would have to be presented showing "how and when and to what extent, and at what cost the energy gap can be filled".

Strangely perhaps, the presentation of alternative energy sources has been made by ex-motorway campaigner, John Tyme. Stephen Salter of Edin- 
burgh University explained wavepower systems, prophesying that the first string of 50 "nodding ducks" will be in the sea off the north of Scotland by 1984. Dr Peter Musgrove of Reading University put four hundred windmills into the Wash in the 1990s to produce around a quarter of Britain's energy demand at a price not far above the cost of coal now. His figures are becoming firmer every year. Solar power, biomass, seabed organic sediment fluidisation, combined heat and power, fluidised bed combustion were all at different stages into the future with corresponding scarcity of operating costings. But more traditional benign systems like water power, tidal power, and of course conservation were available options today.

The problem is money, either for research or first generation operating plants. All the witnesses giving evidence on sofit energy paths claimed Britain was being slow in investigating alternative options. Amory Lovins' book Soft Energy Paths, which appeared during the inquiry, rapidly became the 'bible' on the way and the will for a move towards these options.

Time-scale has been Justice Parker's concern. John Tyme's trump card has been Yorkshire miners' leader Arthur Scargill, presenting the case for bridging the gap before a soft energy future with a huge expansion of the coal industry. This almost worked, although BNFL did a pretty savage job in crossexamination on both the productivity record and safety record of the coal industry in comparison with the nuclear industry.

The energy establishment represented by the Central Electricity Generating Board (CEGB), the South of Scotland Electricity Board (SSEB) and the Department of Energy itself faced a barrage of criticism from objectors. Surplus generating capacity, the downturn in energy demand since the oil crisis, and a radical change in energy coefficients of new innovations were cited as proof that present energy demand forecasts are far too high. In particular, Dr Peter Chapman from the Open University Energy Research Group tied up the present view of energy relying on supply needs, with the need to change to a soft energy scenario based on energy income.

The nuclear industry is of course cursed with one emotive argument above all-the Bomb. The inquiry has not denied that nuclear warfare is a terrifying prospect. But British Nuclear Fuels has been at pains to deny that it is a conceivable prospect for future generations living with large quantities of plutonium resulting from reprocessing. Britain will be custodian to fifty tons of plutonium by the end of the century if THORP goes ahead. Five tons would fuel the first commercial fast reactor CFR 1 . Throughout the inquiry the shadow of safeguards and security has been cast over the proceedings.

The fall-out from this has gone in three directions-towards terrorism, international nuclear diplomacy and civil liberties. BNFL thought they had squashed terrorism by their insistence that "measures" could be taken to prevent theft of plutonium. "Spiking" (making it radioactive), only returning it on contract as refabricated fuel, and the sheer difficulty of making a device that explodes rather than produces a large criticality excursion, are enough of a deterrent to BNFL. They add that there are easier ways to achieve political ends without dabbling in radioactive materials.

But BNFL's confidence was rudely shaken by two American witnesses. Professor Arnold Wohlstetter from the University of Chicago has explained to the inquiry that a nuclear device has been exploded using reactor-grade plutionium in the USA. Tom Cochran, again from the NRDC in Washington, DC, presented evidence outlining the

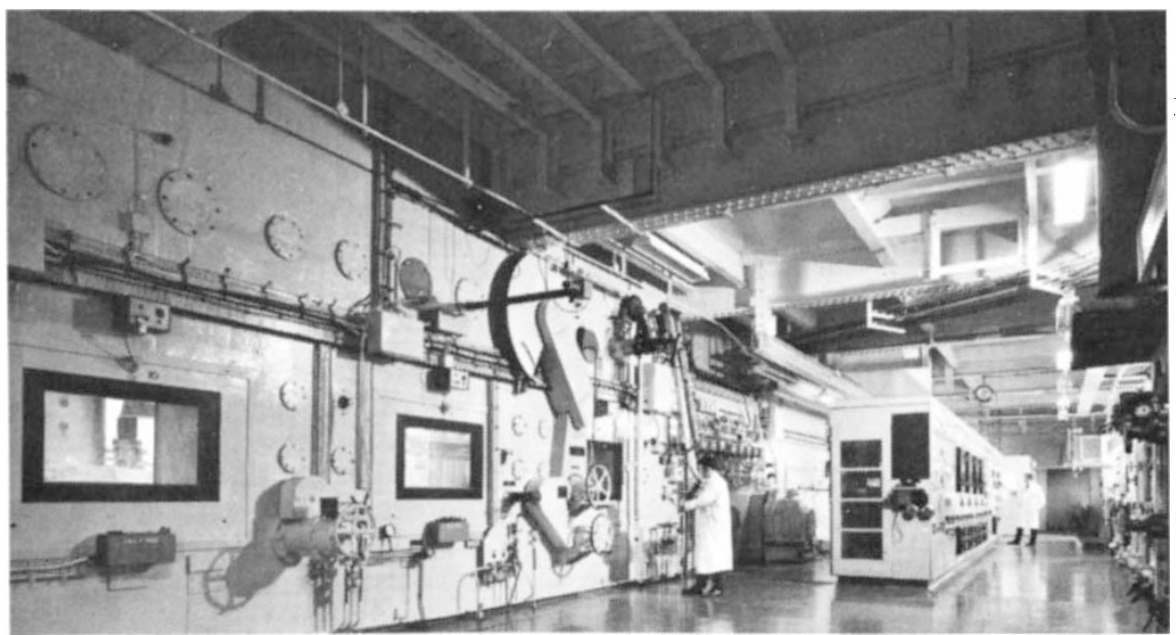

Windscale's head-end plant: no longer working, it has reprocessed oxide fuel numbers needed for an armed raid on a nuclear plant (around nine outside and three inside.)

\section{Avoiding proliferation}

FOE have maintained a consistent line on the international threat of plutonium proliferation. They see as inevitable the political pressures for reprocessing contracts that specify return of plutonium after a certain period. The motivating force of Walt Patterson, their scientific adviser, has been proliferation, with a specific image of a world where shipments of plutonium will become familiar, leaving contempt for safeguards to provide the inevitable disaster.

Positive suggestions to avoid proliferation have been made by Professor Joseph Rotblat from London University. He favours an international bank for buying in, storing, and allocating nuclear materials to establish the nuclear industry as a global enterprise. Research into storage options, reprocessing and the fast breeder would all be done under international licence. Reprocessing would be abandoned until proved essential.

Whatever the solution to proliferation, the attempt is to avoid the Orwellian 'plutonium economy'. Both the National Council for Civil Liberties and Justice made pleas that future generations would not be committed to a life of surveillance, power parks guarded by automatic weapon carrying police, and hunits for subversives.

By holding a mental map of all this in his head, Justice Parker has gained immense respect for the intellectual feat he is attempting. The weight of evidence is with the objectors, there being more of them, but he will be typically concerned with common sense applied to reprocessing now in Britain.

In retrospect Whitehaven has been an essential part of the spectacle. Inquiry faithfuls staying in enclaves throughout the town have been indulging in increasingly frenetic energy outlets as time goes on. Beach barbecues, pony-trekking, and a treasure hunt, where a vital clue was missing leaving ten stranded inquirers tearing around the Cumbrian countryside in complete confusion, have added colour to the interminable days of evidence and cross-examination.

Foreign visitors comment on the lack of armed police at the doors and the politesse of the participants. Perhaps it's one of the problems of the inquiry that the British will never see something as that important. The feeling now as summing up begins is "we wish $t$ the end of term party would come". But although the work is ending for some, for Justice Parker it is just beginning. 